\title{
THE PANORAMA OF TRANSLATIONS OF BRAZILIAN AND PORTUGUESE LITERATURE INTO THE SLOVENE LANGUAGE (1991-2018)
}

\author{
Mojca Medvedšek \\ Blažka Muller Pograjc \\ Universidade de Liubliana / Eslovênia
}

\section{ABSTRACT}

The first translations from Portuguese into Slovene appeared in the twentieth century. Most of the translations were published after the Second World War when Slovenia was still part of the Socialist Federative Republic of Yugoslavia and was integrated in a much larger and linguistically diverse cultural territory. The article presents the historical panorama of translations of Brazilian and Portuguese literature into Slovene, highlighting the history of the last twenty-seven years following the independence of Slovenia i.e. from 1991 onwards.

KEYWORDS: Translation history; Brazilian and Portuguese literature; translation of literature; Slovene language

\section{Introduction}

The aim of this article is to present the results of a small study carried out between January and June of 2018 and to show the characteristics of the translation of literature in Portuguese language into Slovene and such translation activities from the onset thereof (1925) until the present day in Slovenia (2018). The analysis comprises three phases, beginning with the first years (i.e. from 1925 until the Second World War), the period of the former Yugoslavia (from 1945 to 1991), and the most recent period since Slovene independence, i.e. from 1991 to 2018. 
The results will be incorporated into a more exhaustive investigation that will aim to describe the history of the translation of literary works in Romance languages in the territory of Slovenia in the $20^{\text {th }}$ century. This project is the result of the collaboration of a few translators and scholars, and received some support from the Association of Literary Translators of Slovenia (DSKP).

\section{Short historical context}

The time of the appearance of the first translations from Portuguese into Slovene corresponds to the period of the so-called "first Yugoslavia", which came into existence as the Kingdom of Serbs, Croats and Slovenes, following the collapse of the Austro-Hungarian Empire after the First World War (1918). It re-emerged from Nazi occupation in 1944, after the Second World War, as the Socialist Federal Republic of Yugoslavia (SFRY), led by the former Partisan leader Josip Broz, i.e. Marshal Tito. The federation consisted of six republics: Bosnia and Herzegovina, Croatia, Macedonia, Montenegro, Serbia, and Slovenia. It was a complex political and cultural space boasting a diverse ethnic, linguistic, and religious composition, consisting of Catholic, Orthodox, and Protestant Christians, Muslims, Jews, and atheists, with several official languages of communication (Serbo-Croatian, Macedonian, Slovene) as well as a high degree of cultural independence in the educational system and regarding publishing policy.

The interest in the Portuguese language in former Yugoslavia at the academic level started late in the day; the first academic possibility to study Portuguese language and literature arose in Zagreb (1985), which was the only capital of the constituent republics in that political entity to systematically offer courses in Portuguese language, literature, and culture.

Therefore, it is not very difficult to understand that Slovenia (independent since 1991) does not have a long or productive tradition in translating literature from Portuguese into Slovene.

In reviewing the relevant sources ${ }^{1}$, it can easily be observed that until the 1990s literature in Portuguese language was not very well known in Slovenia and that only a limited number of works and authors had been published; other evidence demonstrating low interest in lusophone literature are the very few documents in the form of critiques and almost non-existent reviews in specialised journals or any other type of investigation at the university level. 


\section{The first translations (1925-1945)}

Slovenes gained the first literary translation from the Portuguese language in 1925. Curiously, the first selected and translated author was Afonso Lopes Vieira (a Portuguese poet, 1878-1946); however, the first work translated into Slovene was not his collection of poetry, but rather the novel O Romance de Amadis (1923), as chosen by the translator Anton Debeljak (1887-1946). The reasons for his decision are not entirely clear. Debeljak, a language professor at the University of Ljubljana - which was founded in 1919 - who was also a translator from French and Spanish and a poet interested in Romance language literature, would have chosen the work of Lopes Viera, beside the fact that Viera's novel is recognized as an important work of Portuguese canon, for some personal reason. In fact, the note on the first page of the book kept in the Slovene National and University Library clearly indicates that this novel was translated with the permission of the author, Lopes Viera. ${ }^{2}$ The decision to publish it was most probably the result of a previous publication of the novel in the form of a feuilleton (1924) in the local newspaper Ljubljanski Zvon. ${ }^{3}$ During his extensive career as a promoter of foreign - primarily Romance - languages ${ }^{4}$, the translator Debeljak also published the first translations of a selection of Camões's poetry as well as the first presentation of Portuguese poetry; both dossiers were published in a cultural supplement of the newspaper Ljubljanski Zvon in $1933 .^{5}$

A long silence followed these first publications.

\subsection{Translations after the Second World War (1945-} 1991)

After the Second World War, literary translations from the Portuguese language into Slovene began to appear more frequently. As mentioned above, at that time Slovenia was still a part of the Socialist Federal Republic of Yugoslavia, and between 1945 and 1991 five works of Portuguese literature, eight works of Brazilian authors, and one work from Cape Verde were published. Until the independence of Slovenia in 1991, especially in the 1960s and 1970s, Slovene readers were able to discover the following Portuguese authors and works: one of the first transitions after the Second World War was Eça de Queirós' O Primo Basilio (1966); followed soon after by Alves Redol's A Barca dos Setes Lemes (1966), as well as António Lobo Antunes's novel Os Cus de 
Judas (1976) and Aquilino Ribeiro's Quando os Lobos Uivam (1978). The translation masterpiece of the 1970's was the publication of the long expected Os Lusíadas in 1976, arousing much interest from both critics and the public. This first version of $O s$ Lusíadas, made by the translator Andrej Capuder (1942-2018), was a shorter version containing only a partial translation of the ten cantos of this epic Portuguese oeuvre, but it was presented to the public with an extended postface on Camões and his time. ${ }^{6}$

As for the translation of Brazilian literature during the same decades, the most translated and published author was Jorge Amado ${ }^{7}$ with five works; the first was curiously not only the first translation from Brazilian, but also the first publication of lusophone literature after the Second World War: Terras do Sem Fim was published in 1956, followed by $O s$ Subterrâneos da Liberdade (1962), Gabriela, Cravo e Canela (1965), Os Pastores da Noite (1968), and Teresa Batista Cansada da Guerra (1979). Other works published and translated at the same time included José Veiga's A hora dos Ruminantes (1981), João Ubaldo Ribeiro's Sargente Getúlio (1984), a play by Lygia Fagundes Telles translated in 1990 for the National Radio, as well as a collection of popular Brazilian short stories entitled A Menina Estrela.

The translation of Baltazar Lopes (Chiquinho, 1989), an author originating from Cape-Verde is the only representative work of lusophone literature not originating in Brazil or Portugal.

An examination of the catalogues also shows that the number of literary translations published between 1945 and 1991 was not only poor in number, but also that the vast majority of these translations from Portuguese into Slovene were indirect, having been made via Italian, Russian, German, Spanish, or Serbo-Croatian. ${ }^{8}$

We can only cite a rather small number of names that appear systematically as translators and authors of prefaces or postfaces regarding works translated into Slovene: Janko Moder (1914-2016), Tine Debeljak (1903-1989), Andrej Capuder (1942-2018), Alenka Bole Vrabec, as well as Jože Dolenc (1912-1994) and Ilse Polack.

The authors of this research would like to emphasise two main reasons for this situation: the first important explanation is the fact that Slovenia, being part of the SFRY between 1945-1991, was included in a larger cultural territory and had school programs that required study of the Serbo-Croatian language, which permitted the average educated Slovene 
reader to read Portuguese and lusophone literature mainly through SerboCroatian translations, which were available at book sellers and in public libraries in much greater number.

The authors of this research presume that the second important reason for the lack of interest in literature in Portuguese is most likely the non-existence of a department of Portuguese language and literature studies, although university study programmes focusing on Romance languages, literatures, and cultures (Italian and French) were established the same year that the first Slovene university opened in Ljubljana (1919) and the Department for Hispanic Language, Literature and Culture Studies was inaugurated in Ljubljana in 1987.

Even though Slovenia did not have a large or flourishing tradition of translating in the time of former Yugoslavia, a review of the Yugoslav registers ${ }^{9}$ of translations shows that some authors, such as Amado, would invariably be translated separately in Serbia, Croatia, and sometimes in Macedonia and Bosnia and Herzegovina as well. Clearly there was a need amongst the different peoples of Yugoslavia, even in the early years, to have their own specific translations. This would definitely be rich territory for translation studies, which would also reveal a variety of translation strategies that take the differences between existing translations beyond the most obvious aspects of lexicography, syntax, and idiom.

\subsection{History of translation after the independence of Slovenia (1991-2018)}

Our brief summary of the history of translation in Slovenia will also aim to evaluate the development and dynamics of the literary translation of literature in Portuguese language between 1991-2018, taking into account exclusively - as in previous sections - translations of books of literature, thus not encompassing articles, poems, or stories published in literary magazines.

Following independence in 1991, the policy of providing financial support for translations in Slovenia changed. The National Culture Program established a list of literary works selected as preferred; thus, a basic priority list of the canon of literatures in Portuguese language appeared with suggestions as regards what should be translated into Slovene.

Financial support for these translations was sent to the publishers and distributed by the National Book Agency; this programme of support 
has significantly increased the number of books translated and shows a conscious and pedagogical effort by both publishers and translators to provide readers the possibility of reading and understanding the so-called classical literature in Portuguese language.

Another major change in translation policy following the independence of Slovenia was the decision of publishers to prefer direct translations from Portuguese into Slovene. This decision coincided with the formation of a new generation of translators who, in most cases, finished Portuguese studies outside Slovenia.

\subsubsection{Translations of literary works in numbers}

An examination of COBISS, the Slovene national database of bibliographic data, reveals that the total number of translated works of Portuguese language (from 1925-2018) is 179. This number is obviously misleading because it also takes into account all reprints and second or third editions of the same titles, as well as articles, radio plays, and fiction and non-fiction books. But given these general terms, from the Second World War until 1991, 30 titles in total were published (and the number of published literary works was 14 , as we showed in the previous section), and the data following the independence of Slovenia show that between 1991 and 2018 Slovenia gained approximately 149 titles translated from Portuguese, of which 90 belong to the category of books; among them, approximately 40 works are translations of Portuguese authors, and about 50 works are translations of authors who write in the Portuguese language.

There is also an important discrepancy when comparing this data with Unesco's Index Translationum, which registers only 44 translated titles.

Speaking of the period after the independence, the proportion of Portuguese authors translated into Slovene and authors who write and publish in the Portuguese language is therefore reasonably balanced Portuguese authors account for $45 \%$ of the translations, while authors who write in the Portuguese language (i.e. Brazilian and African authors) account for $55 \%$. Thus, a majority of the titles (approximately 50 ) were written by authors (i.e. Brazilian and African) who write in the Portuguese language; of those 50 titles, only 9 (representing 18\%) are literary works - the majority of the published works belong to esoteric, religious, or popular literature.

As for the publication of the works of Portuguese authors in 
Slovene, we can observe that of the 40 works, 29 , i.e. $65 \%$ of the titles, fall within the category of so-called classical fiction literature; the remaining $15 \%$ are a varied mix of cookbooks and religious, self-help, touristic, and esoteric books.

The authors of this article would like to emphasise that 37 titles published after 1991 fall within the category of classical literature; the distribution of translations by literary genre is as follows: most translated works are works of fiction - novels, essays, and short stories - $(90 \%)$, with poetry representing a smaller percentage of these publications (16\%), while only one dramatic work has been translated and published (4\%).

3.2.2. Authors and works translated after the independence of Slovenia (1991-2018)

The first substantial effort to present a work of a classical Portuguese author to the Slovene readership was the translation of Fernando Pessoa, which calls for special attention since he is the most esteemed and translated author of all Portuguese authors.

Pessoa's first translations were published in literary journals in the early 1990s. Between 1997 and 2013, six different publishers, translated by four different translators, published six titles. It is interesting that all of the earliest translations of Pessoa were generally done by poets: Ciril Bergles (1934-2013) and Miklavž Komelj were the first translators and researchers of Pessoa, along with Barbara Juršič (O Livro do Dessassego, 1999) and Mojca Medvedšek, who realised a translation of a selection of his letters, essays, and short stories in an ambitious project, managed by the major Slovene poet Komelj, intended to present selected works of Pessoa in 500 pages.

In 2007, five years after its first publication in book form, the first play translated from Portuguese was staged by the Slovene National Theatre (Drama) in Ljubljana, i.e. Fernando Pessoa's O Marinheiro in Komelj's translation. This acclaimed work clearly increased interest in Portuguese literature.

Interestingly, this was not the only attempt in the dramatic sphere. In 2013, another play - A Educação do Estóico (The Education of the Stoic, translated by Mojca Medvedšek) written by Pessoa's heteronym Barão de Teive, was presented at the Anton Podbevšek National Theatre in Novo Mesto and selected as one of the best theatrical works at the Boršnikovo Srečanje theatre festival in 2014. 
Several reviews were published in the media, and the following critique was written in the programme provided to theatregoers:

The performance is a very clean attempt at presenting certain philosophical thinking on stage in such a manner that would not limit it to a simple linear recital. The actors playing the Baron's servants function like a well-oiled machine. Their moves are precisely choreographed. The gears of the mechanism do not have their own personalities, but their words are rather the words of Barão de Teive. The only person on stage is the Baron. The tone of the performance is very even, almost monotonous. There is no dramatic turn and the dramatic struggle stems merely from playing around with the philosophical musings of Barão de Teive ${ }^{10}$.

The author who follows the work of Fernando Pessoa in terms of visibility and importance is José Saramago (1922-2010), who is deemed to be a modern master. Most of his published novels ${ }^{11}$ - five - were published in Slovenia between 1998 and 2014, after he received global recognition by being awarded the Nobel Prize in 1998. Barbara Juršič is the translator of all five novels.

In 2016, the Mini Theatre staged Saramago's work Ensaio sobre a cegueira, which was a unique project realised by one of Slovenia's best directors and ensembles. Their interpretation of the work, which required great effort and daring ambition, further increased the interest of Slovenes in Saramago. Upon the relatively recent premiere of the performance, the director wrote the following:

This performance - perhaps more than any other [staged at the Mini Theatre] - actively involves the audience. On one hand, it allows them complete freedom as regards their imagination and moral and ethical beliefs, while on the other, they have to sit through a 100-minute-long interpretation of Essay on Blindness. Therefore, it is a synaesthesia in the narrower sense of its meaning ${ }^{12}$.

The third most published author belongs to a younger generation of authors: Gonçalo M. Tavares (1970). Between 2008 and 2018, four of his novels and selected short stories were published. He visited and presented his work on two occasions $(2008,2009)$ at different literary events - one of them being part of the cycle entitled Literary Identities of Europe, organised by the Modrijan publishing house.

Poetic anthologies comprise $12 \%$, i.e. 3 titles, of all published works in Slovene; these collections generally attempted to cover the lack 
of a more general view of the history of Portuguese poetry, as well as to bridge the need to create ties between the two countries and cultures.

The first anthology, 13 Vozes Portuguesas, translated by Mojca Medvedšek, Blažka Müller Pograjc, and Mateja Rozman, is an anthology of contemporary Portuguese poetry (2009) that reveals the main voices of $20^{\text {th }}$ century poetry, and the second, Poetas Portugueses e Eslovenos (2012), is a bilingual continuation that provides a panoramic view of $20^{\text {th }}$-century Portuguese poetry to the interested Slovene and Portuguese public; the latter publication was an ancillary product of the cultural partnership between Gumarães and Maribor, who in 2012 were declared Cultural Capitals of Europe.

Within the structure of literary genres, it can also be observed that there is a clear absence of works in the social sciences and humanities - sociology, philosophy, linguistics, and history - with the exception being some texts included in the select works of Fernando Pessoa, and a minimal presence of dramatic works.

We believe that the presence of the classical authors, public presentations, as well as the positive response from the critics have aroused general interest in authors of literature in Portuguese language. Nevertheless there is no academic research on the reception of translations of Portuguese literature in newspapers or specialised reviews, magazines, or academic publications.

As for the translation of Brazilian literature in the same period, it can be observed that the level of popularity of Amado's oeuvre has not been reached.

One of the most translated and published authors is the $19^{\text {th }}$-century classical Brazilian author Machado de Assis, with a selection of his short stories (2012) and the novel Memórias Póstumas de Brás Cubas (2017). The contemporary author Cristóvão Tezza also has two publications and two of his novels have been translated and published by different publishing houses: Uma Noite em Curitiba (2011) and O Filho Eterno (2013).

It can be noted that translations of works by C. Tezza also received a great deal of attention from reviewers, which could be due to the fact that the topics he addressed go beyond literature in the narrow sense and extend into the field of sociology; therefore, they are interesting, for example, to professionals working in the field of special education.

The following two classics should be included in the group of books written by the most prominent contemporary authors: Agua 
Viva e a Hora de Estrela (2006) by Clarice Lispector, which remained completely unnoticed, especially among reviewers, and a collection of poetry by Carlos Drummond de Andrade (2011), the first attempt to translate Brazilian modernist poetry. Besides these two publications, the relatively short list of works translated from Brazilian Portuguese during this period contains certain other works intended to attract the attention of the broader public, especially due to their political engagement and connection to popular music (e.g. Chico Buarque, 2011).

Nevertheless, the Slovene translation of a work written by an acclaimed Brazilian author who is established in several fields, i.e. Chico Buarque (the same holds true with regard to Clarice Lispector), remained almost unnoticed by academic critics and reviewers despite the fact that the translation was published by a fairly large and respected Slovene publisher. It was reviewed only once. Such could be ascribed to the fact that this writer is less well known in Slovenia and is thus relatively uninteresting to the public, even though he is an important persona in Brazilian culture.

The anthology entitled Rdeča luna (Lua Vermelha, 2011) was an attempt to fill a lacuna as regards Brazilian poetry and included selected Brazilian poets born between 1920 and 1970. The first period covered in the anthology comprises poets who began to write after the end of the Second World War and who mixed avant-garde, modernism, and traditional styles. The representatives of the second period are mainly intellectuals who explored the borders of language and metaphorical expression. The third, youngest, generation paved the way for postmodernism. Thus, the book offers an integrated view of the lyrical poetry of a land that is still viewed as terra incognita in Slovenia.

As can be expected, in the period 1991-2018 a number of critical reviews and opinions appeared in periodicals and the media addressing writers noticeably present on the international literary stage - above all those who had the most works translated into other languages or had received international awards (e.g. Saramago).

In Slovenia, a greater number of reviews and opinions accompanied translations of works recognised as belonging amongst the best within national literatures and written by the authors considered to be the most esteemed names of those same national literatures, e.g. Machado de Assis in Brazil and Pessoa and Saramago in Portugal.

Furthermore, the authors of this paper would like to emphasise that 
in Slovenia, critical reviews and opinions published in periodicals and the media only occasionally address the translator's work by means of a critical evaluation of the quality of the translation. This fact would seem to indicate that literary translations into Slovene - a language spoken by a mere 2.5 million native speakers - are very common and therefore hold an important place within the milieu of Slovene culture. Unfortunately, the sphere of literary criticism does not perceive translations in such a manner, as only occasionally does a review include an interview with the translator - who is, after all, a specialist on a certain translated literary work and the broader cultural context that such occurred in and in which its author is active.

\section{Conclusion}

The publication and translations of literary works in Portuguese increased substantially in Slovenia after 1991. The method that the authors applied in this article - in order to understand the different dynamics in the period between 1925 and 2018 - should be understood as an effort to formulate a basic outline of the history of the literary translation in Slovenia and to present a general picture of the situation and activity regarding translations from Portuguese into Slovene.

Another finding of this study is that within the past decade, in comparison to older periods, Slovenia has witnessed an increase in the production of critical reviews and opinions regarding literary translations from Portuguese. The authors assume that this is a consequence of several factors: i) an increase in the number of translations of works originally written in Portuguese published in the most recent period; ii) the increased number of such translations published in the Slovene cultural milieu have increased people's familiarity with lusophone literature, as well as the awareness that lusophone literature is a part of lusophone culture; iii) in this most recent period, as compared to previously, a larger number of literary translators specialised in Portuguese language and lusophone literature have been active in Slovenia.

Although interest in lusophone literature and culture in this part of Central Europe clearly exists, especially since 1991, still more effort should be devoted to ensuring an efficient and systematic presentation of the global literary heritage that the ocean of literature in Portuguese language represents. And this is a further task for translators, publishers, and scholars. 


\section{O PANORAMA DAS TRADUÇÕES LITERÁRIAS DA LITERATURA DE LÍNGUA PORTUGUESA NA ESLOVÊNIA (1991-2018)}

\section{RESUMO}

As primeiras traduções da literatura portuguesa para o esloveno apareceram no século XX. A maioria das traduções foi publicada após da segunda guerra mundial, quando a Eslovênia ainda fazia parte da República Federativa Socialista da Jugoslávia e era parte de um território cultural muito maior e linguisticamente diverso. $\mathrm{O}$ artigo apresentará o panorama histórico das traduções eslovenas da literatura portuguesa para a língua eslovena, destacando a história dos últimos vinte anos após a independência da Eslovênia, ou seja a partir de1991.

PALAVRAS CHAVE: tradução da literatura; história da tradução; literatura brasileira e portuguesa; língua eslovena.

\section{REFERÊNCIAS}

\section{SOURCES}

Catalogue of the Central Library of the Humanities of the Faculty of Arts, University of Ljubljana.

Catalogue of the Library of the Department of Romance Literatures and Languages, Faculty of Arts, University of Ljubljana.

Catalogue of the National and University Library, Ljubljana:

- The card catalogue organised alphabetically by author for the period 1948-1965

- The card catalogue organised by subject for the period until 1965

COBISS - the national database of bibliographical data (a collective catalogue and database of all Slovene libraries), accessible at: $<$ http://www.cobiss.si/ $>$ (20- 
6-2018)

INDEX TRANSLATIONUM:

$<\mathrm{http} / / /$ www.unesco.org/xtrans/bsform.aspx?lg=0> (20-06-2018)

BOOKS

BAJT, Drago. Svetovna poezija na pragu novega stoletja. In: Hieronymus, Ljubljana, v. 2, n. 1-2, p. 113-121, 2008.

BULOVEC, MODER Janko. Bibligrafija prevodov v slovenščino (1945-1960). Ljubljana: DSP, 1960.

GRUM, Mitja. Slovenski prevajalski leksikon 1550-1945. Ljubljana: ZRC SAZU, 2007.

MODER, Janko. Slovenski leksikon novejšega prevajanja. Ljubljana: Obzorja, 1985.

Modrov zbornik: 23. Zbornik DSKP. Bio-bibliografije članov DSKP. Ljubljana: DSKP, 1998.

KERNC, Elizabeta. Slovenski biografski leksikon. Ljubljana: Jugoslovanska tiskarna, 1925-32.

RUSINOW, Dennison. The Yugoslav Idea before Yugoslavia. In: DJOKIĆ, Dejan, ed.. Yugoslavism: Histories of a Failed Idea 1918-1992, London: Hurst and Company, p. 11-26, 2003.

Savremeni književni prevodioci Jugoslavije. Beograd: Savez književnih prevodilaca Jugoslavije, 1970.

STANOVNIK, Majda. Slovenski literarni prevod: 1550-2000. Ljubljana: Založba ZRC SAZU, 2005.

STANOVNIK, Majda. Prevajalci o prevodu. Ljubljana: DSKP, 2013.

\section{NOTAS}

1 The investigators consulted all of the accessible physical and online catalogues of the National and University Library in Ljubljana in May and June 2018.

2 In: Catalogue - 1965. See also Bulovec, Moder (1960).

3 KERNC, 1925, p. 32

4 MODER, 1985, p. 52

5 The tile of the selection was Iz portugalskega pesništva (Poesia portuguesa escolhida) 
and included such poets as: Almeida Garret, Araujo, Bocage, Braga, Castro, Lacerda, Ferrira, Amorim, Junqueiro, Pascuaes, Quental, Vicente, etc. (MODER, 1985, p. 52).

6 CAPUDER, 1976, p. 92-118.

7 Amado was one of the most translated autors on the territory of foreign Yougoslavia.

8 See COBISS, the national database and online catalogue: <https://plus.si.cobiss.net/ opac7/bib/search>

(20-6-2018).

9 See also the catalogue Savremeni književni prevodioci Jugoslavije (1970).

10 accessible at: $<$ http://www.antonpodbevsekteater.si/si/dogodek/vzgoja-stoika/ $>$ (20-62018)

11 For the titles, see the Appendix.

12 accessible at: $<$ http://www.mini-teater.si/si/articles/3303/esej-o-slepoti $>$ (20-5-2018)

\section{APPENDIX:}

List of works translated between 1925 and 2018

List of works translated from Portuguese to Slovene language 1945:

VIEIRA, Afonso Lopes. Amadis. Ljubljana : Vigred, 1925.

CAMÕES, Luis Vaz de. Sonetje ljubezni. Ljubljanski zvon, 1925. (Sonetos).

List of works translated from Portuguese to Slovene language from 1945 to 1991: ANTUNES, António Lobo. Hudiču v riti. Murska Sobota : Pomurska založba, 1988. (Os Cus de Judas).

EÇA DE QUEIROS, José Maria. Bratranec Bazilij. V Ljubljani : Cankarjeva založba, 1966. (O Primo Basílio)

CAMÕES, Luis Vaz de. Luzitanci. Ljubljana: 1976. (Os Lusíadas)

*LOPES, Baltazar. Chiquinho. Murska Sobota : Pomurska založba, 1989.

REDOL, Alves. Mož s sedmimi imeni. Ljubljana : Mladinska knjiga, 1966. (Os homens e as sombras)

List of works translated from Portuguese language 1991-2018: 
Antologija. 13 portugalskih glasov. Ljubljana: Center za slovensko književnost, 2009. (Antologia)

Antologija. Zgodbe iz Portugalske. Ljubljana: Sodobnost International, 2009. (Antologia, Contos escolhidos)

Antologija. Slovenski in portugalski pesniki. Gumarães: Capital Europeia da Cultura, 2012. (Poetas escolhidos)

ANTUNES, António Lobo. Spodbujanje krokodilov. Ljubljana: Cankarjeva založba, 2003. (Exortação aos crocodilos)

BRITO, Casimiro. Opus affettuoso. Ljubljana: Center za slovensko književnost. 2002.

BRITO, Casimiro. Na mojstrovi poti. Ljubljana: Center za slovensko književnost, 2013. (Antologia)

BRANDÃO, Raul. Humus. Ljubljana: Beletrina, 2013.

CARDOSO, Dulce Maria. Vrnitev. Ljubljana: Cankarjeva založba, 2014. (O Retorno)

CARNEIRO, Mário de Sá. Lucijeva izpoved. Ljubljana: Modrijan, 2011. (A Confissão de Lúcio)

*COUTO, Mia. Zadnji plamenčev let. Ljubljana : Študentska založba, 2005. (O Último Voo do Flamingo)

JORGE, Lidia. Dolina strasti. Ljubljana: Mladinska knjiga, 2007. (O Vale da Paixão)

JORGE, Lidia. Mož in druge zgodbe. Ljubljana: Pristopi-Literatura, 2013. (Marido e outros contos)

LISBOA, Adriana. Simfonija v belem. Ljubljana : Modrijan, 2017. (Sinfonia em Branco)

MELO, Filipa. To je moje telo. Ljubljana: Učila, 2010. (Este é o meu corpo)

PESSOA, Fernando. Zadnja čarovnija (izbrano delo). Ljubljana: Nova revija, 1997. (O último sortilégio)

PESSOA, Fernando. Knjiga nespokoja. Ljubljana: Cankarejeva založba, 1999. (O Livro do Desassossego)

PESSOA, Fernando. Pomorska oda. Ljubljana: Aleph, 2002. (Ode Marítima)

PESSOA, Fernando. Bankir anarhist, Mornar. Ljubljana: LUD Šerpa, 2003. (O banqueiro anarquista, Marinheiro)

PESSOA, Fernando. Psihotipija (izbrano delo). Ljubljana: Mladinska knjiga, Kondor, 2007. (Obra escolhida) 
PESSOA/BARON DE TEIVE. Vzgoja stoika. Ljubljana: LUD Šerpa, 2008. (A Educação do Estóico)

TAVARES, Gonçalo M. Gospodje. Ljubljana: Študentska založba, 2008. (Os Senhores)

TAVARES, Gonçalo M. Jeruzlem: črne knjige. Ljubljana: Modrijan, 2008. (Jerusalém)

TAVARES, Gonçalo M. Naučiti se moliti v dobi tehnike. Ljubljana: Modrijan, 2009. (Rezar no tempo da técnica)

TAVARES, Miguel Sousa. V tvoji puščavi. Ljubljana: Modrijan, 2013. (No Teu Deserto)

SALDANHA, Ana. Za starejše od šestnajst. Medvode : Malinc, 2017. (Para maiores de dezasseis).

SARAMAGO, José. Esej o slepoti. Ljubljana : Cankarjeva založba, 1997. (Ensaio sobre a Cegueira)

SARAMAGO, José. Zapis o samostanu. Radovljica : Didakta, 1999. (Memorial do Convento)

SARAMAGO, José. Evangelij po Jezusu Kristusu. Ljubljana : Cankarjeva založba, 2005. (O Evangelho Segundo Jesus Cristo)

SARAMAGO, José. Kajn. Ljubljana : Modrijan, 2011. (Caim).

SARAMAGO, José. Kameni splav. Ljubljana : Modrijan, 2014. (A jangada da pedra)

List of translated Brazilian works between 1945-1991:

AMADO, Jorge. Dežela na koncu sveta. V Ljubljani : Cankarjeva založba, 1956. (Terras do Sem Fim)

AMADO, Jorge. Katakombe svobode. V Ljubljani : Cankarjeva založba, 1962. (Os Subterrâneos da Liberdade)

AMADO, Jorge. Gabriela kot nagelj in cimet: kronika mesta v provinci. Maribor : Obzorja, 1965. (Gabriela, Cravo e Canela)

AMADO, Jorge. Pastirji noči. Maribor : Obzorja, 1968. (Os Pastores da Noite)

AMADO, Jorge. Viva Tereza. Maribor : Obzorja, 1979. (Teresa Batista Cansada da Guerra)

DOLENC, Jože Zvezdna deklica, brazilske ljudske pripovedke. Ljubljana: Mladinska knjiga, 1977. (Contos)

RIBEIRO, João Ubaldo. Seržant Getúlio. Murska Sobota : Pomurska založba, 
1984. (Sargento Getúlio)

RIBEIRO, Aquilino. Ko volkovi tulijo. Murska Sobota : Pomurska založba, 1978. (Quando os Lobos Uivam)

VEIGA, José. Ura prežvekovalcev. Murska Sobota : Pomurska založba, 1981. (A Hora dos Ruminantes)

List of translated Brazilian between 1991-2018

Antologija. Rdeča luna. Ljubljana: Sodobnost International, 2011. (Lua vermelha) ASSIS, Machado de. Dušeslovec in druge zgodbe. Ljubljana: Sanje, 2012. (Contos)

ASSIS, Machado de. Posmrtni spomini Brása Cubasa. Ljubljana: LUD Šerpa, 2017. (Memórias Póstumas de Brás Cubas)

BUARQUE, Chico. Budimpešta. Ljubljana : Študentska založba, 2011. (Budapeste)

CARVALHO, Bernardo. Devet noči. Ljubljana : Modrijan, 2013. (Nove noites)

DRUMMOND de Andrade, Carlos. Občutje sveta. Mladinska knjiga: 2012. (Antologia)

LISPECTOR, Clarice. Živa voda ; Čas zvezde. Ljubljana : Nova revija, 2006. (Água Viva; A hora da estrela).

MATOS, Narlan. Pesmi o vetru in mojem življenju. Ljubljana: Aleph: 2013. (Antologia)

RIBEIRO, João Ubaldo. Hiša blaženih bud : Razvrat. Ljubljana : Mladinska knjiga, 2007. (A Casa dos Budas Ditosos)

TEZZA, Cristovão. Noč v Curitibi. Novo mesto : Goga, 2011. (Uma Noite em Curitiba)

Recebido em: 31/08/2018

Aceito em: 02/12/2019 